\title{
Urban micro-scale flood risk estimation with parsimonious hydraulic modelling and census data
}

\author{
C. Arrighi ${ }^{1}$, M. Brugioni ${ }^{2}$, F. Castelli ${ }^{1}$, S. Franceschini ${ }^{2}$, and B. Mazzanti ${ }^{2}$ \\ ${ }^{1}$ Department of Civil and Environmental Engineering, University of Florence, Florence, Italy \\ ${ }^{2}$ Arno River Basin Authority, Florence, Italy
}

Correspondence to: C. Arrighi (arrighi.chiara@gmail.com)

Received: 4 September 2012 - Published in Nat. Hazards Earth Syst. Sci. Discuss.: Revised: 12 March 2013 - Accepted: 29 March 2013 - Published: 31 May 2013

\begin{abstract}
The adoption of 2007/60/EC Directive requires European countries to implement flood hazard and flood risk maps by the end of 2013. Flood risk is the product of flood hazard, vulnerability and exposure, all three to be estimated with comparable level of accuracy. The route to flood risk assessment is consequently much more than hydraulic modelling of inundation, that is hazard mapping. While hazard maps have already been implemented in many countries, quantitative damage and risk maps are still at a preliminary level. A parsimonious quasi-2-D hydraulic model is here adopted, having many advantages in terms of easy set-up. It is here evaluated as being accurate in flood depth estimation in urban areas with a high-resolution and up-todate Digital Surface Model (DSM). The accuracy, estimated by comparison with marble-plate records of a historic flood in the city of Florence, is characterized in the downtown's most flooded area by a bias of a very few centimetres and a determination coefficient of 0.73 . The average risk is found to be about $14 € \mathrm{~m}^{-2} \mathrm{yr}^{-1}$, corresponding to about $8.3 \%$ of residents' income. The spatial distribution of estimated risk highlights a complex interaction between the flood pattern and the building characteristics. As a final example application, the estimated risk values have been used to compare different retrofitting measures. Proceeding through the risk estimation steps, a new micro-scale potential damage assessment method is proposed. This is based on the georeferenced census system as the optimal compromise between spatial detail and open availability of socio-economic data. The results of flood risk assessment at the census section scale resolve most of the risk spatial variability, and they can be easily aggregated to whatever upper scale is needed given that they are geographically defined as contiguous polygons. Damage is
\end{abstract}

calculated through stage-damage curves, starting from census data on building type and function, for the main categories in the study area: structures, household contents and commercial contents. This method is tested in the area of the St. Croce district in Florence, one of the most seriously affected in the famous 1966 flood.

\section{Introduction}

Floods are one of the main natural disasters in terms of losses of human life and economic damages. The 2011 flood in Thailand for instance, caused 40 billion dollars of overall losses; the 2002 flood in central Europe, 16.5 billion euros (Munich RE, 2012). In the European Community (EC) countries it has been estimated that in the 1970-2006 period the average annual flood loss was about 4 billion dollars (Barredo, 2009).

With the 60/2007/EC directive, European countries have to implement hazard and risk mapping to develop a districtscale risk management plan; in Italy about $45 \%$ of the municipalities are at high hydro-geological risk (Ministry of Environmental, 2000), so flood risk mapping has a strategic role in flood prevention and risk mitigation measures. In Europe many studies on the impact of the climate change show that some regions are prone to a rise in flood frequency such as northern and north-eastern Europe (Lehner et al., 2006) and at a continental level $18.7 \%$ of the territory is exposed to high flood hazard (Lugeri et al., 2006).

Flood risk is commonly defined as the product of flood hazard, vulnerability and exposure. In the present study the vulnerability is considered as the expected degree of damage 
experienced by an exposed asset between 0 and 1 (total destruction) as in Luino et al. (2009), Oliveri and Santoro (2000) and Su et al. (2005). Flood risk estimation requires the quantification of all the above three components. Fully quantitative approaches enable one to understand the cost-effectiveness of flood protection measures and helps municipalities and public institutions in allocating proper resources to face the emergency and recovery phases of flood disasters.

Identifying flood prone areas, usually the first step in flood risk studies, requires the implementation of hydrologichydraulic models that enable one to quantify the evolution of a flood and its hydraulic representative variables (e.g flood depth and velocity). Hazard maps resulting from hydraulic models usually show potential flood extent, water depth and sometimes velocity for predefined low, medium and high probability levels.

The sustainable complexity of a model depends on the amount of available data and computational resources. Flood propagation in urban areas is clearly bidimensional, with peculiar features that depend on the complex interaction between the flow and the streets/buildings pattern, especially when the urban texture is very dense as in many historic town centres.

In many cases 1-D numerical models are considered as adequate for the estimation of flood water levels in rivers with regular flow patterns and as the preliminary identification of inundation zones (Apel et al., 2004; Messner and Meyer, 2005b; Messner et al., 2007). When there are more complex river geometries and inundation flow patterns are relevant for the precise mapping of local parameters, the use of 2-D model becomes unavoidable (Büchele, 2006; Apel et al., 2008; Ernst et al., 2010). Diffusive full 2-D models are potentially more accurate than 1-D or quasi-2-D models, but they are more difficult to apply systematically to large areas if only traditional elevation data are available. They require two crucial pieces of information to achieve their potential accuracy: the detailed topography of the flow domain, including buildings and infrastructures, and its representative roughness. Lidar-based aerial surveys generate high quality topographic data and enable one to obtain a complete, high resolution (e.g. order of $1 \mathrm{~m}$ nominal spacing or even less) and up-to-date digital surface model (DSM). Recently, this kind of product has become increasingly available also in dense urban areas, so in this respect the problem is no more in the data availability, it is rather in the computational difficulties, resolution and structure of the computational grid, related to the streets/buildings pattern. The determination of roughness coefficients also needs an accurate and high resolution land use database, to be eventually augmented with the increase of friction due to irregular topography (Ernst et al., 2010). Here again the problem lies in some peculiarities of the urban environment, such as the interaction of the flow with various types of debris (vehicles, street furniture, etc.) that can easily stack and form temporary obstructions to the flow itself.

The advantages of a "classical" 2-D model over a more parsimonious one can be strongly reduced if other simplifications are required for their practical implementation, such as a steady-state approximation (Ernst et al., 2010) or an upper bound to the computational nodes. 2-D hydraulic models have usually been adopted in portions of sparse urban areas, providing reliable results after calibration studies (Mignot et al., 2006; Apel et al., 2008; Ernst et al., 2010; Schubert and Sanders, 2012; Hunter et al., 2008).

For the present case study many problems arise in the setup of a 2-D model. First of all the computational costs, which are recognized as the major drawback of 2-D models performed with a fine grid size (Begnudelli et al., 2008; Apel et al., 2008; Chen et al., 2012). A grid size of 1 or $2 \mathrm{~m}$ is generally considered as unavoidable to describe the street pattern of many urban environments, especially when historic centres are included, and may lead to long simulations.

Other difficulties emerge in the definition of the computational mesh. The structure of the mesh requires an appropriate use of the DSM in order to represent consistently the buildings/street pattern (Schubert and Sanders, 2012; Chen et al., 2012). To give an idea, the historic centre of Florence is characterized by narrow and irregular streets (about $3 \mathrm{~m}$ wide) that are fundamental to the flood propagation dynamic but difficult to describe even with a $2 \mathrm{~m}$ grid. As panel $\mathrm{b}$ in Fig. 2 hints, the DSM is affected by a number of artifacts that may introduce strong distortion in the hydraulic connectivity of the street pattern. In many cases some areas seem hydraulically disconnected where the streets are so narrow that are hidden by the roof eaves, or the presence of parked vehicles or other temporary objects form unrealistic obstacles to the flow. The restoration of the representative hydraulic connections may then require a quite complex and subjective manual filtering of the original DSM.

Finally, the absence of an adequate set of data for the model calibration may be a further obstacle to the use of 2D models (see Sect. 4.1). This last question is crucial in the assessment of the reliability of the hydraulic model and also in the benchmarking of different approaches. The combination of a 1-D model for the main river channel flow and a 2-D model for the inundated areas is recognized as a good compromise between complexity and accuracy. Shallow water equations or their diffusive wave approximation are theoretically optimal choices for the 2-D part, but the use of storage cells (Bates and De Roo, 2000; Huang et al., 2007; Horritt and Bates, 2000) has been also proposed when the above difficulties arise.

A quasi-2-D model with storage cells, even if potentially less accurate, is less computationally demanding. It also requires, but with a simplified treatment, the same data of a full 2-D model: a number of cross sections for the river stream, a DSM and a limited set of conceptual parameters for the hydraulic links among storage cells. For example Bates et 
al. (2000) (LISFLOOD), uses conceptual channels to transfer flow from one cell-node to the adjacent ones. Filtering of the DSM may be limited to what is needed to estimate unbiased stage-storage curves for each cell, regardless of detailed hydraulic connections.

The route to flood risk assessment is much more than hydraulic modelling of inundation, which is hazard mapping, and it may be logically subdivided in five legs: hydrologic modelling, hydraulic modelling, damage modelling, economic analysis, and risk evaluation.

Currently we can implement high accuracy hazard maps but damage estimation is affected by large uncertainties (Merz et al., 2004) and needs substantial improvement in the complex analysis of vulnerability (Van der Veen and Logtmeijer, 2004), exposure and economic value (Messner and Meyer, 2005a). That is why in Europe many different flood maps are available (van Alphen et al., 2009), such as flood extent maps and flood depth maps, but flood risk maps have not been developed yet in most of the countries (Jonkman et al., 2008).

Flood damages are commonly classified into direct and indirect. The direct damages are due to the physical impact of the water with people/objects, the indirect damages are induced by direct ones and occur outside of the flooded area. These damages can be further classified into tangible and intangible damages depending on the possibility to monetize them. Generally flood risk studies focus on direct tangible damages, because other damages, especially if intangible (e.g. loss of life, interruption of public services, trauma, etc.), are difficult to assess.

Damage models are usually developed at macro- (e.g. at regional level with municipality detail) or meso-scale (e.g. at municipal level with raster mapping at order of $100 \mathrm{~m}$ resolution) using land use databases such as CORINE (Coordination of Information on the Environment) and/or MOLAND (Monitoring Land Use/Cover Dynamics; Genovese, 2006; Apel et al., 2008) and regional statistics (Lindenschmidt, 2006; Su et al., 2005); the few studies on micro-scale (e.g. with the detail of the main streets/buildings pattern) flood damage evaluation are more recent, and the main difficulty in the methodologies proposed so far is their reliance on privately-owned economic data in addition to georeferenced land registry data (Ernst et al., 2010; Elmer et al., 2012). Existing potential damage models (HAZUS,Hazards US; FLEMOps, Flood Loss Estimation Model for the private sector) use stage-damage curves to merge water level and land use maps into potential damage maps. Libraries of stage-damage curves can be created, at meso or micro-scale, collecting data after flood events or synthetically by experts (Oliveri and Santoro, 2000; Luino et al., 2009; Genovese, 2006; ICPR, 2001; Kang et al., 2005; Penning-Rowsell, 2003; Kok, 2001; Reese et al., 2003; Dutta et al., 1998). Other current problems highlighted in these studies are the completeness of spatial coverage of most single-building databases, the local representativeness of predetermined stage-damage curves, and the existence of accessible information on the economic values of exposed assets.

For flood risk assessment in urban areas one crucial issue at the moment is the pursuit of an adequate and significant scale of analysis supported by adequate information-rich databases at the same level of spatial detail.

Given the above state of the art, the main purpose of the present study is to demonstrate the feasibility of a microscale flood risk mapping methodology with a balanced accuracy and spatial detail of the various estimation steps. Looking at systematic applicability as a required characteristic of the methodology, this means searching for parsimony in the hydraulic modelling part and exploiting the maximum information content from standard socio-economic databases in the following damage analysis steps.

A quasi-2-D model where the urban flood prone area is represented by a system of related storage cells is here adopted, thus avoiding the need of intrinsically uncertain determination of the roughness map and of the cumbersome definition of computation grids. Moreover, as described in Sect. 2, the hydraulic scheme can be easily implemented with off-the-shelf public domain software models, while making maximum use of modern lidar based DSM products. Section 3 describes a new micro-scale damage analysis procedure, based on the proposal of the census section as optimal compromise between spatial detail and systematic availability of required socio-economic data. Feasibility and performance of the various steps are assessed in Sect. 4, where the methodology is applied to the St. Croce area in Florence, one of the most seriously affected in the famous 1966 flood. To further demonstrate the usefulness of quantitative microscale flood risk mapping, the results are used to evaluate the economic convenience of building retrofitting measures in the area.

\section{Quasi-2-D hydraulic modelling}

Once the flood scenarios are known after the hydrologic analysis, the hydraulic model is the second module of the risk assessment procedure followed by damage modelling, economic analysis and risk evaluation. This second step should produce the flood depth maps required to evaluate the per cent damage through stage-damage relationships in the second step. Once coupled with maps of exposed monetary values, the flood risk can be finally estimated taking into account the different probabilities of the simulated flood scenarios (Fig. 1).

Taking into account the above risk estimation procedure, the hydraulic model adopted here is composed by two parts: 1-D unsteady flow model for the river and a quasi-2-D storage cell model for the urban flood prone area. This model is a refinement of the current instrument for flood hazard mapping in the Arno river basin (PAI, Arno River Basin Authority, 2002b), which now includes the DSM for the detailed 


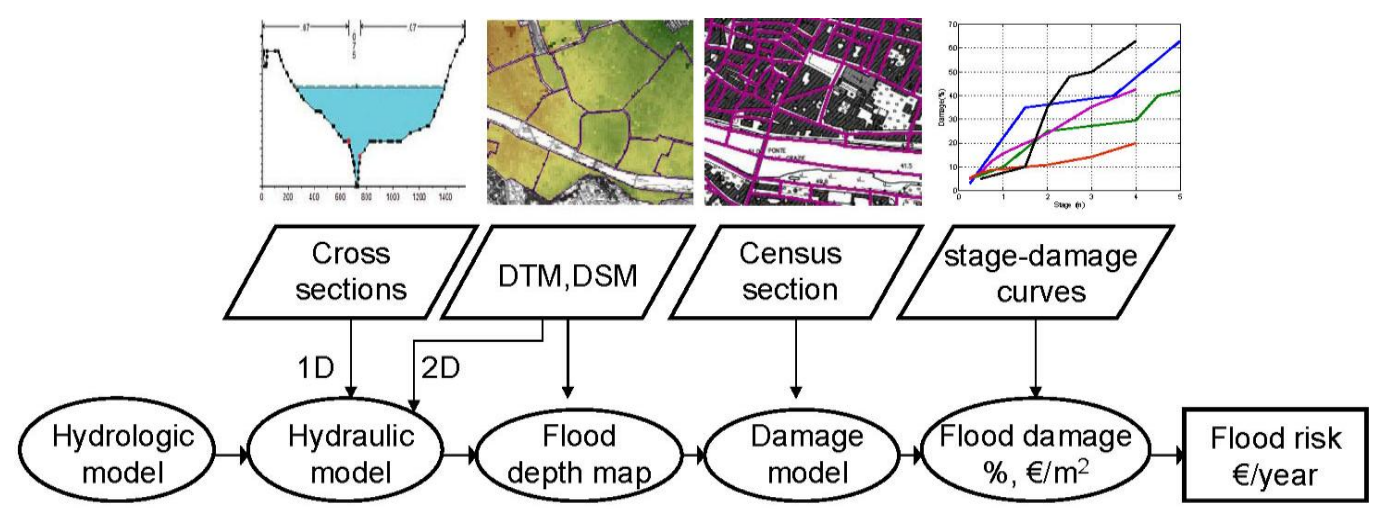

Fig. 1. Main flow chart for urban micro-scale flood risk assessment.

(streets/buildings scale) representation of the flow domain. The DSM of the study area is derived by lidar data with kriging and it is characterised by a horizontal resolution of $1 \mathrm{~m}$ by $1 \mathrm{~m}$ and a vertical accuracy of $0.15 \mathrm{~m}$.

\subsection{Model construct}

The computation of the flood propagation and corresponding water profile along the river(s) is performed through a standard solver of the 1-D general equation of unsteady flow, such as the one provided in the well known HEC-RAS (Hydrologic Engineering Centers River Analysis System) package.

The quasi-2-D hydraulic model for the floodplain consist of several storage areas (cells) whose effective geometry is estimated from a meter-scale DSM. Buildings are, by default, considered as waterproof blocks. A certain level of porosity can be also added for those non-waterproof buildings with relevant storage capacity. Water levels within cells and flow between them are computed using the continuity equation, the DSM-based stage-storage relationships and the weir law for the conceptual elements connecting neighbouring cells (Fig. 2a). The continuity equation provides the evolution in time of the water volume $V$ of each cell.

$\frac{\mathrm{d} V}{\mathrm{~d} t}=\sum_{i} Q_{l, i}$,

where $Q_{l, i}$ is the flow above the $i$-th connecting weir, considered as positive when entering the cell and negative otherwise.

The stage-storage relationship for each storage cell is expressed in the parametric form:

$V=a\left(z-z_{0}\right)^{n}$,

where $V$ is the storage volume, $z$ is the water surface elevation, $z_{0}$ is the minimum terrain elevation within the cell, $a$ and $n$ are two parameters that are estimated by best-fitting a series of $(z, V)$ points computed from the DSM with a standard GIS tool, once the cell boundary has been defined as described in Sect. 2.2. The standard broad-crest weir flow equation is used to compute water movement along the cells system:

$Q_{l}=c_{\mathrm{d}} L \cdot(2 g)^{\frac{1}{2}} \cdot\left(z-h_{0}\right)^{\frac{3}{2}}$,

where $g$ is gravity, $L$ is the equivalent length of the spillway crest, $h_{0}(\mathrm{~m})$ is the weir crest elevation and $c_{\mathrm{d}}$ is the discharge constant taken equal to 0.35 .

When the downstream head on the weir $z_{\mathrm{d}}-h_{0}$ is larger than $0.67\left(z-h_{0}\right)$, the flow on the weir has a backwater effect and Eq. (3) is transformed into

$Q_{l}=\left[c_{1}\left(z_{\mathrm{d}}-h_{0}\right)+c_{2}\left(z-z_{\mathrm{d}}\right)\right] \sqrt{2 g\left(z-z_{\mathrm{d}}\right)}$,

where $c_{1}$ is $0.65, c_{2}$ is $0.4, z_{\mathrm{d}}$ is the downstream water elevation.

The 1-D model for the river is physically disconnected, because the banks have a larger elevation than the floodplain. Thus, here we refer to the backwater effects only between the cells of the floodplain.

Flood input to the storage cell model is given through river bank elements in the 1-D model. These are represented as lateral weir structures so that overflow hydrographs are automatically computed as in standard river flood routing calculations. Parameters of lateral weirs, i.e. of potential overflow initiation points, require a detailed survey of river banks and levees that is however commonly available around flood prone urban centres.

This model returns the water surface elevation in the storage areas for every instant of computation so, if the storage areas have an adequate not-too-large dimension, it is possible to reproduce the key features (e.g. main timing and depth variability across the city extent) of the dynamics of flood propagation. Also, the quasi-2-D part is here simulated with HEC-RAS but can be easily implemented with a GIS toolbox for an even more efficient in-out data management. 


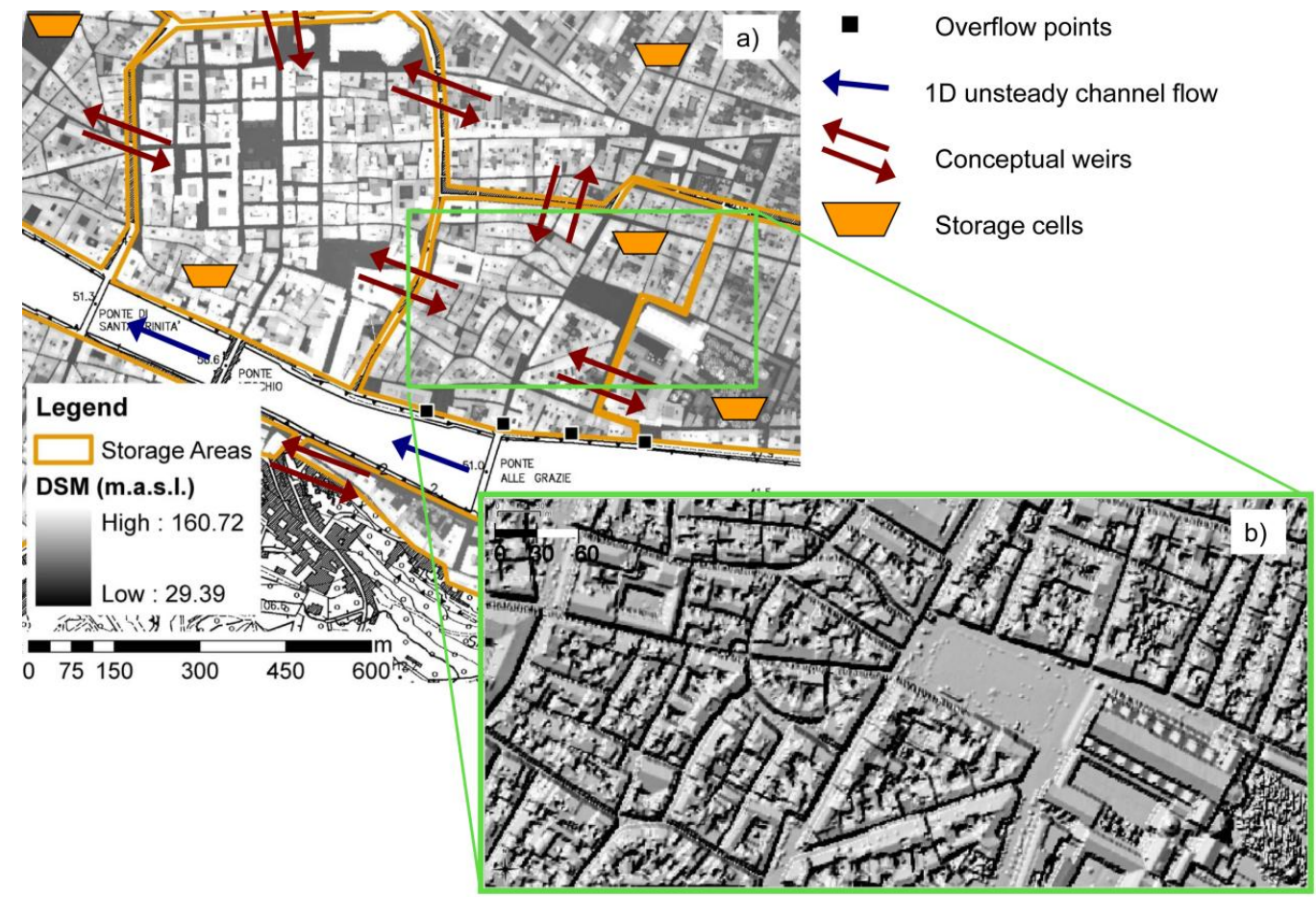

Fig. 2. Scheme of the quasi-2-D hydraulic model (a), superimposed on the digital surface model (DSM) of the downtown study area of Florence and a zoom of the St. Croce area with a hillshade effect (b).

\subsection{Parameters estimation and data requirements}

One further advantage of the hybrid quasi-2-D hydraulic modelling is the possibility to consistently merge different sources of topographic data for the main river and the flood prone area. The 1-D river model can be set up using standard high-precision river surveys (cross sections and bank and levees profiles) that are routinely updated and made available by basin authorities and similar agencies. More and more frequently lidar-based aerial surveys form the basis of the urban DSM. Both pieces of information are efficiently managed through dedicated GIS toolboxes, which also provide direct interfaces to hydraulic models such HEC-RAS or directly compute storage curves inside prescribed polygons. Here a hybrid version between a DSM and a DTM (digital terrain model) is used in order to consider as obstacles to the flow only the buildings and the infrastructures and not the vegetation.

The most delicate step in the terrain data set-up is the delineation of the storage cell boundaries. These are here drawn with quite a large level of subjectivity, in a GIS assisted environment, considering the presence of anthropic discontinuity such as elevated streets and railway overpasses, pre-setting a reference cell equivalent diameter of the order of the inundation depth (e.g. a very few meters) times the topographic gradient along the main flood propagation path (e.g. a very few per-thousands), and avoiding an excessive heterogeneity of terrain elevation within the cell. The joint use of the DSM and DTM may be useful at this stage. Although the definition of the storage cells can seem too subjective, in most situations the boundaries of the cells are determined by terrain elevation discontinuity, given the presence of the urban infrastructures.

The "virtual" hydraulic structures connecting different storage areas are weirs or weirs and culverts where there is an underpass. Culverts have the real dimension of car underpasses while weir elevation is extracted from the DSM in the linking segment between two storage areas. Every linking segment has its elevation profile from which the crest elevation is extracted as the average elevation of the profile. The length of the weir is assumed to be comparable to the effective portion of the storage area edge in which water can flows (e.g. roads connecting two cells). Since we do not have an adequate set of data for the hydraulic model calibration the weir coefficients (Eqs. 3 and 4) are taken from literature tables for broad-crested weirs.

The main disadvantages of this quasi-2-D approach are the quite large subjectivity in drawing the storage cells and the fact that the storage cells start to fill in the lowest part. As above described, the first problem can be solved using a predefined reference cell size, the latter is much more crucial in unbounded areas, but in this case study the area is characterised both by natural bounds (the hills on the left bank) and anthropic discontinuities. The larger slopes are close to 
the river banks, so, realistically, these areas are only of flow transit (Fig. 5a). Nevertheless this model is able to reproduce correctly the flood dynamics only when the lowest part of the cell is the closest to the river.

\section{Damage modelling and risk estimation}

\subsection{Purposes and problems}

A key step in the proposed methodology is the realisation of a georeferenced GIS polygonal feature that gives indications about consequences of flooding on urban assets of various kinds. In this example we choose to consider only direct tangible damages to structures, household contents and commercial contents, the more relevant categories in the example study area are described in the next section. These damages are quantified first as per cent loss through the application of stage-damage functions and then as monetary loss per unit surface area $\left(€ \mathrm{~m}^{-2}\right)$.

Stage-damage functions in terms of percent loss have the advantage of being applicable to similar urban environments also in very distant areas, thus allowing to largely draw them from existing literature. In the example described here about the city of Florence, Italy, damage curves for the cities of Palermo, Italy (Oliveri and Santoro, 2000) and Prague, Czech Republic (Genovese, 2006) have been considered because the characteristics of the buildings of these urban areas are comparable (presence of the cellar, number of storeys). The micro-scale approach is crucial at this stage, as it allows the specification of buildings and commercial characteristics that form the basis for assessing the similarities between distant urban areas.

After stage-damage function application, per cent losses can be transformed into economic losses using monetary value maps for each class. Monetary values are hardly available directly at the micro-scale, but a number of proxy variables may be considered to downscale monetary estimates from regional and sectorial economic studies. As an example, real-estate market value may be used as a proxy indicator for structures and household contents, or the annual business income as (one) proxy for the value of commercial contents. However also these proxy variables, for a number of reasons such as the privacy or the market value of the data itself, are usually not available for the single unit (household, business, etc.), but can be found in various databases only at some aggregation level.

Here we consider the census section system as the optimal compromise between aggregation scale of many different socio-economic data and spatial detail required for a urban micro-scale study. Census section polygons compose an irregular mesh, covering all territory with anthropic activities, usually more dense right where the population density increases. In Italy, as an example, census section usually coincides with building blocks in densely urbanized settlements.
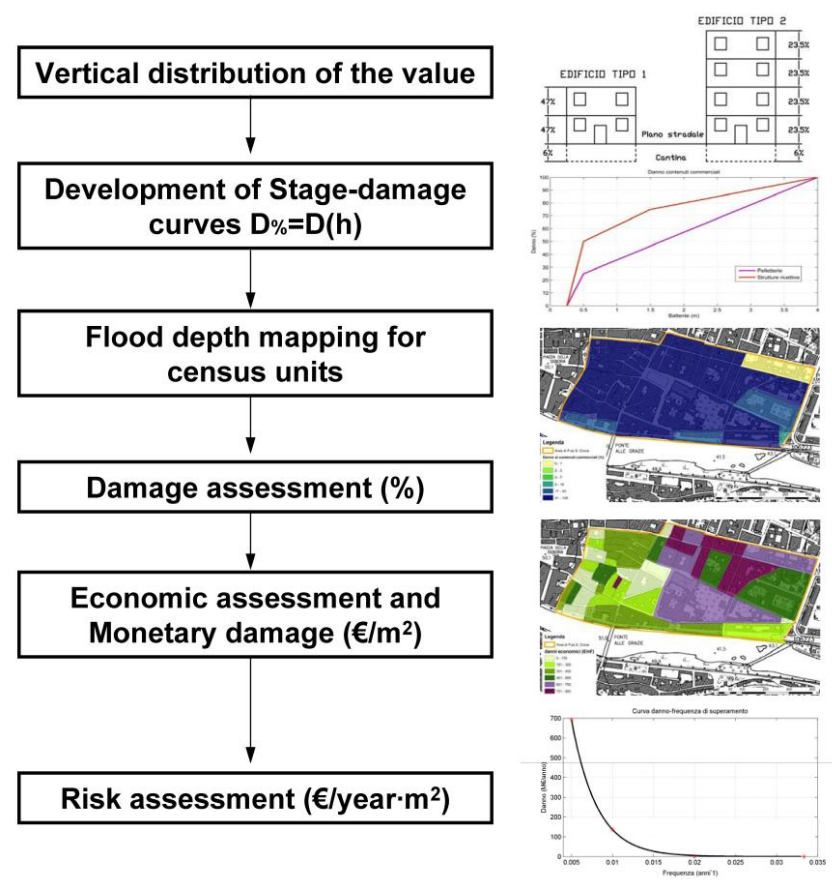

Fig. 3. Risk assessment procedure based on census section scale.

Every country in Europe has its statistics office that provides population, apartments and commerce census, so a census section micro-scale could be used in many countries.

Despite the large amount of information in census databases, as detailed below, the choice of a full quantitative approach at the micro-scale still implies the need of on-site inspections to collect additional information about the characteristics of buildings and commercial activities needed to refine local stage-damage curves, especially when these are drawn from the literature. These inspections, however, may be limited to a very few representative samples for each category taken into consideration.

\subsection{Damage analysis process}

The flowchart with the main steps of the damage analysis process is sketched in Fig. 3. After the flood depth is obtained from the hydraulic simulation, the average flood depth for census section is computed through GIS tools: flood depth map for a selected scenario, i.e. return period or probability level, consisting of a raster grid with the same size and resolution of the DSM used for the floodplain hydraulic model. The GIS raster calculator enables one to compute the average flood depth value inside each census section polygon. This average flood depth value for each census section represents the independent variable in a stage-damage relationship. Flood velocity is here neglected as a possible further factor in damage assessment because, according to recent studies, velocity in monetary loss modelling cannot be 
Table 1. Summary of the damage categories considered and their indexes.

\begin{tabular}{|c|c|c|c|}
\hline $\begin{array}{l}\text { Damage } \\
\text { Categories }\end{array}$ & $\begin{array}{r}\text { Monetary } \\
\text { value } \\
\left(€ \mathrm{~m}^{-2}\right)\end{array}$ & $\begin{array}{r}\text { Average per } \\
\text { cent damage } \\
(\%)\end{array}$ & $\begin{array}{r}\text { Monetary } \\
\text { damage } \\
\left(€ \mathrm{~m}^{-2}\right)\end{array}$ \\
\hline Structures & $V_{\mathrm{s}}$ & $D_{\mathrm{S}}$ & $D_{\mathrm{s}}$ \\
\hline Household contents & $V_{\mathrm{cr}}$ & $D_{\mathrm{cr}}$ & $D_{\text {cr } €}$ \\
\hline Commercial contents & $V_{\mathrm{cc}}$ & $D_{\mathrm{cc}}$ & $D_{\mathrm{cc}} €$ \\
\hline
\end{tabular}

recommended in absence of a large amount of validation data (Kreibich et al., 2009).

Damage assessment proceeds with the application of stage-damage functions obtaining the average per cent damage for census section and category and finally, by simple multiplication with the monetary values, with the evaluation of monetary losses for each category. This analysis considers three main damage categories: structures, household contents and commercial contents. The different damage categories and the indexes used in the next sections are summarized in Table 1.

\subsection{Variables and equations}

A stage-damage curve returns the damage $d$ associated to a flood depth $h$ above street level:

$d_{k i}=d_{k i}(h)$,

where $k$ is a damage category (e.g. structures, household contents... ) and $i$ is a sub-category of $k$ (e.g. buildings with different number of storeys).

The average damage $D_{k} \%$ for each main category results from a weighted average in the census section:

$D_{k \%}=\frac{\sum_{i=1}^{m} d_{k i}(h) \cdot n_{k i}}{\sum_{i=1}^{m} n_{k i}}$,

where $n_{k i}$ is the amount of objects belonging to $k i, m$ is the number of sub-category considered.

The economic loss $D_{k}$ per unit area is the product of average percent damage, economic value $V_{k}$ per unit area and vulnerability $c$ (see Sect. 3.4 ),

$D_{k}=c \cdot D_{k} \% \cdot V_{k}$

In order to estimate economic values for the categories of structures and household contents, real estate appraisals $Q_{\text {imm }}$ may be used as a good proxy variable:

$V_{\mathrm{s}}=\frac{p \cdot A_{\mathrm{ed}} \cdot Q_{\mathrm{imm}}}{A_{\mathrm{sc}}}$

where $p$ is the average number of storeys in the buildings of the census section, $A_{\mathrm{ed}}$ is the built area, $A_{\mathrm{sc}}$ is the census section area, and $V_{\mathrm{s}}$ is the structure value for census section unit area (e.g. the market value of a building block). Household contents value $V_{\mathrm{cr}}$ is supposed to be a fraction $f$ (see Sect. 3.4) of $V_{\mathrm{s}}$ :

$V_{\mathrm{cr}}=f \cdot V_{\mathrm{s}}$.

Resulting economic and damage values are then per unit area of census section. Expressing values as per unit area of census section is more convenient than per unit real estate area, that would be the common market representation, because census section polygons usually cover the urban area with no gaps. Calculations of average or total quantities at large scales, such as neighbourhood or municipality, may be then computed by simple summation.

Micro-scale quantitative economic data are even more difficult to find, on accessible databases, for business in general and commercial activities in particular, obvious reasons are strict privacy requirements, trade regulations, etc. It is quite common the case where only national or regional annual average incomes per trade sector are available. We can assume in general that quantitative economic data on the commercial sectors are available at a spatial scale much coarser than the urban micro-scale, so that proxy variables have now the role of downscaling and "localizing" these data. An example of such a proxy variable is the number of employee per sector in a census section. This can be used to downscale average regional values through the assumption that a larger economic value of a business or a commercial activity, even within a broad category, usually results in (or is consequence of) a larger number of employees. As detailed in Sect. 3.4, regional and sectorial data can be used to estimate the average monetary value per employee $V_{\text {ad }}$ of a commercial activity of a given kind in the area, and from this the corresponding total value in each census section $V_{\text {cc }}$ may be estimated as:

$V_{\mathrm{cc}}=\frac{\sum_{j=1}^{n} V_{\mathrm{ad}}(j) \cdot \operatorname{ad}_{\mathrm{sc}}(j)}{A_{\mathrm{sc}}}$,

where $\operatorname{ad}_{\mathrm{sc}}(j)$ is the number of employees in activity $j$ in the census section.

\subsection{Required data and damage parameters}

Damage assessment as outlined above requires the estimation of several parameters. Data sources for their estimation may vary from country to country, but the core census databases may be considered to have similar characteristics in most of them. Also additional data, such as real estate appraisals at municipal levels or sectorial studies on business and commercial activities at regional or national level, may be supposed to be available for a large set of urban centres worldwide. As an example among various possibilities, the following data sources have been used for the case study in Sect. 4. 
- Population and apartments census (Istat 2002);

- Industry and tertiary census (Istat 2002);

- Real estate appraisals (Agenzia del territorio, 2011);

- Trade studies (Agenzia delle entrate, 2009).

The National Statistics Institute (ISTAT) census provides in Italy a large amount of data about buildings, apartments, population and economic activities. Similar data are provided by the Office for National Statistics in England or the Statistichen Ämter des Bundes und der Länder in Germany. For each census section quite a large number of data is systematically provided: the number of buildings and their destination, the number of storeys, the period of construction, and the number of employees for a specific activity, just to name a few that are used in the damage estimation procedure.

Published trade studies provide in Italy the national average income for a trade activity while real estate appraisals provide the local market value for sale and renting at submunicipal, i.e. neighborhood, level.

In many cases replacement or substitution value is chosen when estimating the value of an estate for damage assessment. Instead, in this study the use of the market value coupled with vulnerability, as further described below, implicitly bears the recovery cost. Whether to adopt the replacement value or the recovery cost as the best indicator for risk estimation has been debated in some studies (Oliveri and Santoro, 2000; Meyer and Messner, 2005a). It may be reasonable to prefer the replacement value only when the expected damage approaches $100 \%$, which is not the case in most urban centers in cases of flooding.

Real estate appraisals and reports on sale trends, which consider different conservation states of buildings, may be also used to define a range of values for the vulnerability parameter $c$ in Eq. (6). Depending on building type and maintenance status, flood damage may in theory vary from very little to complete destruction. In the considered case study, where most of the real estate are well maintained ancient masonry buildings, we assume that after a flood a typical building will just require a prominent renovation (e.g. restoration of electrical and heating plants, building frontage, floors and interiors). From real estate appraisals, the ratio between the market value of a flat that needs a deep renovation and a perfect condition flat is within the range $0.15-0.30$ so that vulnerability for structures $c$ is assumed to be around 0.2 (Agenzia del territorio, 2011).

On the contrary, contents are usually much more vulnerable than structures regardless of building type, so for household contents and commercial contents $c$ is assumed to be 1 , that is to say that the contents (house furniture, appliances, etc.) must be totally replaced if affected by a flood.

From similar reasoning the parameter $f$ in Eq. (9), which is the ratio between building content and building structure values, is estimated considering the ratio between the renting value of an unfurnished flat and a furnished one. Typical values in the study area are in the interval 0.10-0.18 (Agenzia del territorio, 2011), so we assume $f=0.15$.

The estimation of the parameter $V_{\text {ad }}$ in Eq. (10), representing the average value per employee of a commercial business, is quite more complex. In fact the national annual average income $I_{\mathrm{na}}\left(€ \mathrm{yr}^{-1}\right)$ for a trade sector, officially given at national level by the Ministry of Economic Development (trade studies) may give biased estimates in some urban contexts where commercial activities are more profitable than in other cities or country areas. Some local correction factor $L$ must be then introduced for $I_{\mathrm{na}}$ before its application. This correction coefficient may be again estimated with data from the real estate market, and taken as equal to the ratio between the local average renting value for a commercial activity and the national one. For instance, in a big town centre commercial renting values for a fashion store may be from 5 up to 12 times higher than the average national rates (Agenzia del territorio, 2011), so we can assume that an equal-size commercial business of that kind is 5-12 times more profitable. To give an idea, $I_{\text {na }}$ for commercial activity in Italy is $290000 € \mathrm{yr}^{-1}$ (Agenzia delle entrate, 2009), in Florence it is 10 times larger.

Also for commercial businesses some sort of vulnerability must be considered, but with a different meaning with respect to residential buildings and contents (where we consider as the prevalent loss the damage to the furniture). Floods may affect them in two main ways: halting the business for a certain period, and deteriorating or destroying merchandise and shop furniture and appliances. For the trade activities we assume as a more objective damage the loss of the merchandise, because the period of inactivity for a shop is largely subjective and sometimes the trade activities can definitively close after a flood event. This depends on the urban resilience to flood, which is out of the scope of this paper. Considering the loss of the merchandise as prevalent, the problem reduces essentially to estimating what fraction of a business value, usually expressed in monetary income per year, is present at any time in the form of vulnerable merchandise and goods. As a first approach, we can consider for each commercial sector a reference in store residence-time of merchandise $T_{\mathrm{s}}$ (years). For instance in a fashion shop the merchandise stays for about three months (every season the fashion collection is substantially renovated), so if a flood occurs only a quarter of annual income may be lost at most. To achieve a better approximation we can consider that some activities contain "refreshable" goods, typically the merchandise, but also permanent goods such as furniture for a nominal amount $M$ (e.g. $15 \%)$. Putting all together, we obtain the average municipality value for a trade sector $I_{\mathrm{na}} \times\left(L \cdot T_{\mathrm{S}}+M\right)$ that, divided for the average number of employees in the municipality for the selected sector (extracted from Industry and Tertiary census), returns the needed parameter $V_{\text {ad }}$ in Eq. (10). The factors used to evaluate $V_{\text {ad }}$ are summarized in Table 2. 
Table 2. Summary of the parameters used for the evaluation of the average value per employee for the commercial sector described in Sect. 3.4.

\begin{tabular}{lrrrrr}
\hline & $\begin{array}{r}I_{\mathrm{na}} \\
\left(\mathrm{yr}^{-1}\right)\end{array}$ & $L$ & $\begin{array}{r}T_{\mathrm{S}} \\
(\text { years })\end{array}$ & $\begin{array}{r}M \\
(€)\end{array}$ & $\begin{array}{r}V_{\text {ad }} \\
(€ \text { empl. }\end{array}$ \\
\hline Description & $\begin{array}{r}\text { Annual average } \\
\text { income }\end{array}$ & $\begin{array}{r}\text { Local correction } \\
\text { factor }\end{array}$ & $\begin{array}{r}\text { Residence-time } \\
\text { of merchandise }\end{array}$ & $\begin{array}{r}\text { Permanent } \\
\text { goods }\end{array}$ & $\begin{array}{r}\text { Av. value } \\
\text { per employee }\end{array}$ \\
\hline Leather good shop & 290000 & 10 & 0.25 & 0 & 76000 \\
Tourist accomodation & 341500 & 10 & 0.02 & 68500 & 13000 \\
\hline
\end{tabular}

\subsection{Risk assessment}

The damage analysis described above may be repeated for a number of flood scenarios corresponding to pre-defined probability levels, e.g. 30, 50, 100 and $200 \mathrm{yr}$ return periods. With economic loss estimated at any point for different return periods, these values can be interpolated in the frequency domain to get a damage-frequency curve. This curve forms the basis for the calculation of the risk measure, defined as the expected annual damage (EAD). EAD is the sum of the damages caused by all the floods of any possible magnitude, weighted by their probability of occurrence in any one year. If $T_{\mathrm{r}}$ is the return period for which the total economic damage $D_{\text {tot }}$ has been estimated, EAD can be computed as:

Risk $=\mathrm{EAD}=\int_{0}^{1} D_{\mathrm{tot}}\left(T_{\mathrm{r}}\right) \cdot d\left(\frac{1}{T_{\mathrm{r}}}\right)$.

The total economic damage $D_{\text {tot }}$ is here resulting from the sum of monetary damage to structures $D_{\mathrm{s}} €$, household contents $D_{\text {cr } €}$ and commercial content $D_{\text {cc } € \text { : }}$

$D_{\text {tot }}\left(m^{-2}\right)=D_{\mathrm{s}}+D_{\text {cr } €}+D_{\text {cc } €}$.

\section{Case study}

In this section an example is presented to demonstrate the feasibility of the proposed methodology in a real case of some broad interest, which is the risk in downtown Florence, Italy, affected by a famous devastating flood in 1966.

In the city of Florence the only event that has been extensively recorded with the watermarks on the building walls is the 1966 flood. Records from such flood allow a partial verification of the accuracy of the hydraulic quasi-2-D model. Other records from previous events (such as 1333 and 1844) are very limited. The absence of a set of data from the past events makes the evaluation of the hydraulic model quantitatively difficult. As widely recognized, the ideal set of data for the hazard model calibration and validation consists of up and downstream flow hydrographs, mapped inundation extent and inundation depths for the urban areas.

According to the 2007/60/EC directive, the flood events occurred in the past have to be taken into consideration

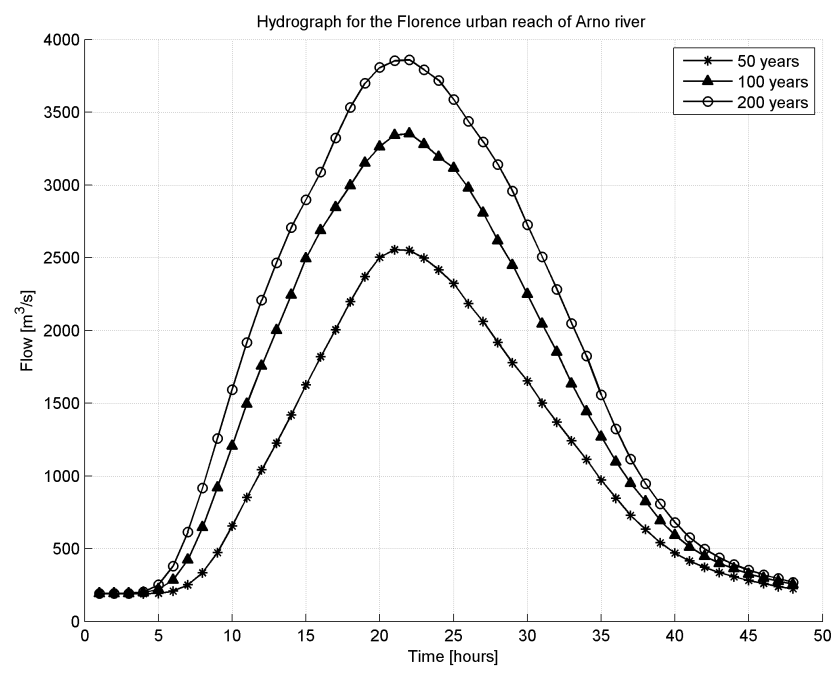

Fig. 4. Hydrographs for the upstream reach of the city of Florence for different return periods.

carefully to understand the future scenarios. However, the correctness of the model here adopted can be only qualitatively evaluated, through the comparison with similar magnitude events, because sufficient data for the calibration and the validation are lacking, as described in the next section.

\subsection{Hydraulic model application}

The hydraulic modelling of the Arno river, applied to the urban area of Florence (Italy), provides a flood depth map for each scenario $(50,100$ and $200 \mathrm{yr}$ floods, see Fig. 4 for the corresponding hydrographs). Hydrologic-hydraulic data and high resolution GIS data are provided by the Arno River Basin Authority (Arno River Basin Authority, 1999, 2002) and by the municipality of the city of Florence.

The Arno river reach inside the urban area is $9.4 \mathrm{~km}$ long. Florence flood prone area is modelled with 42 storage cells, covering $16.5 \mathrm{~km}^{2}$, and 63 connections (weirs or weir and culvert).

For the $50 \mathrm{yr}$ event there are no active overflow points, so this return period will be considered as reference zerodamage probability in the damage-frequency curve used for 


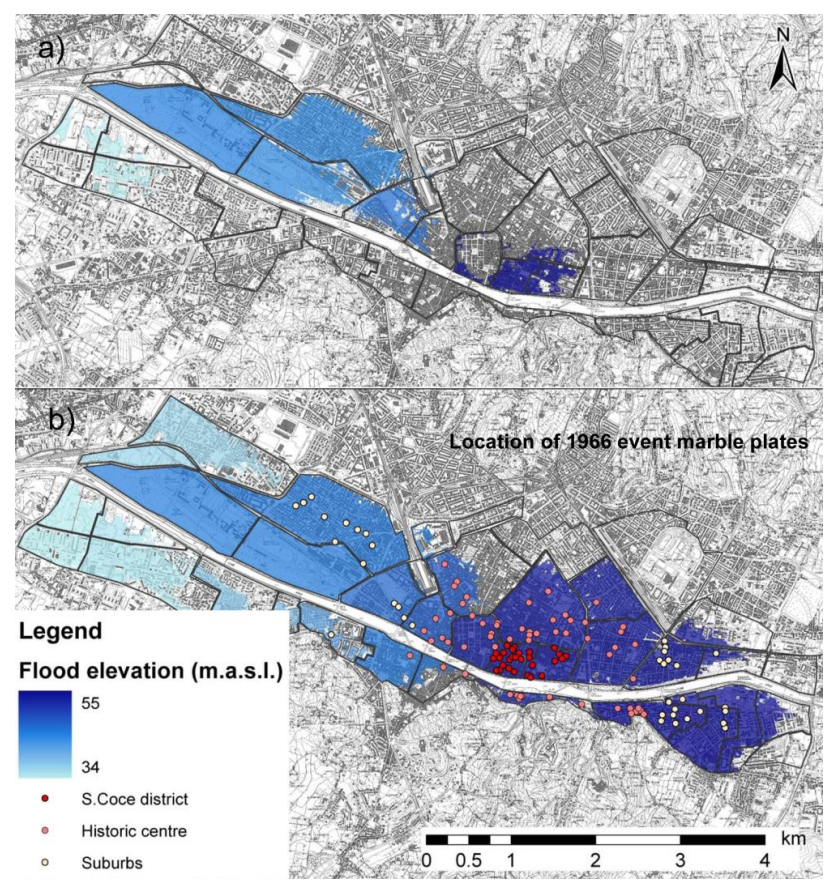

Fig. 5. Maximum flood elevation in Florence for the $100 \mathrm{yr}$ flood (a) and $200 \mathrm{yr}$ flood (b). (a) clarifies that in presence of high slopes close to the river banks these areas are supposed to be of flow transit and consequently not flooded. (b) also shows the location of the historic marble plates reporting the maximum flood depth of the 1966 flood. Different symbols are used for different study areas: red for the St. Croce district, pink for the whole downtown, white for later developed suburbs.

risk estimation. For the $100 \mathrm{yr}$ and the $200 \mathrm{yr}$ scenarios the 1-D river model activates 8 and 16 overflow points, respectively.

In the $100 \mathrm{yr}$ scenario the flooded area is about $3 \mathrm{~km}^{2}$ with an average flood depth of $2 \mathrm{~m}$. In the $200 \mathrm{yr}$ scenario, flood area and depth increase to $11 \mathrm{~km}^{2}$ and $2.5 \mathrm{~m}$, respectively (Fig. 5). The estimated pattern of the $200 \mathrm{yr}$ flood in Florence shows strong similarities with the historic flood of 1966. These similarities are both in terms of flood dynamics and flood depth, especially in the downtown area. In both cases the inundation starts immediately upstream of the urban area, then almost simultaneously downstream in Parco delle Cascine and St. Croce areas on the right bank (Fig. 6), finally also the left bank is inundated. As also shown in Fig. 5, the historic centre is completely flooded after $20 \mathrm{~h}$ from the start of the simulated inundation and surrounding areas follow after $1-2 \mathrm{~h}$. The maximum flood depth is generally reached after about $24-26 \mathrm{~h}$ from inundation start.

The complete observed hydrograph for the 1966 flood is actually available for the section of the Arno river at San Giovanni alla Vena (much further downstream of Florence, about twice the contributing area) and for the section of the Sieve river at Fornacina (one tributary upstream). Consequently an adequate set of data for the hydraulic model calibration/validation in the urban reach of Arno river is lacking. A model reconstruction of the flood peaks is given in Malguzzi et al. (2006). This study and various other technical reports (e.g. Arno River Basin Authority, 2002b) have been used to assign to the 1966 event a recurrence interval between 150 and $200 \mathrm{yr}$. These previous studies allow us to compare the 1966 event with the $200 \mathrm{yr}$ scenario. This comparison has the meaning of validating the model on the basis of events with comparable magnitude. It is evident that, if available, the use of the true 1966 input hydrograph would provide a much better basis for model validation. For this case study it is considered that this "similar-magnitude" comparison is still meaningful for validation purposes, also in view that the adopted model does not require calibration.

The map in Fig. 7 and scatter plot in Fig. 8 compare the $200 \mathrm{yr}$ flood depth model estimates in the Florence study area with existing watermarks of the famous 1966 flood. These watermarks (see example inset in Fig. 6) are marble plates placed on many building walls in downtown Florence. Corresponding 1966 flood water depth at watermarks is officially given by the Arno River Basin Authority as elevation of watermark above pavement level at the time of placement, a few weeks after the flood when water the signature on the walls was still evident.

The scatter points in Fig. 8 are divided into three groups according to their position in the study area (see also Fig. 5 for their location). The black points concern the area of the St. Croce district where marble plates of the 1966 flood are more densely distributed (Fig. 7). The grey points belong to the whole historic centre of Florence and the white ones are from the suburbs (north-west and south-east suburbs).

Considering possible later changes in pavement elevation and a severity of the 1966 flood between 150 and $200 \mathrm{yr}$ recurrence intervals (Arno River Basin Authority, 2002b), the $200 \mathrm{yr}$ model results compare pretty well with watermarks in the whole downtown Florence. More importantly, some remodelling of the river profile and bridge foundations have been done in the years following the 1966 flood, so that the same flooding depths of that event may be now expected with a higher recurrence interval. Error statistics are comparable with data accuracy in the historic centre (RMSE $0.63 \mathrm{~m}$, bias $-0.03 \mathrm{~m}, R^{2}=0.73$ ) and in the St. Croce district (RMSE $0.37 \mathrm{~m}$, bias $0.18 \mathrm{~m}, R^{2}=0.49$ ). In the suburbs the model overestimates the inundation depth (bias $0.27 \mathrm{~m}$ ) with a much larger difference between the model and watermark levels (RMSE $1.85 \mathrm{~m}, R^{2}=-0.59$ ). The poor performance in the suburbs can be easily explained by the fact that in 1966 those areas had not been urbanised yet. Most of the buildings in those areas were constructed after 1970, and consistently the use of the up-to-date DSM implies an overestimation of the flood depths.This discrepancy in the quality of the flood depth estimation further demonstrates the importance of the use of a recent and high-resolution DSM for such hydraulic simulations. The similarity between the $200 \mathrm{yr}$ and the 1966 


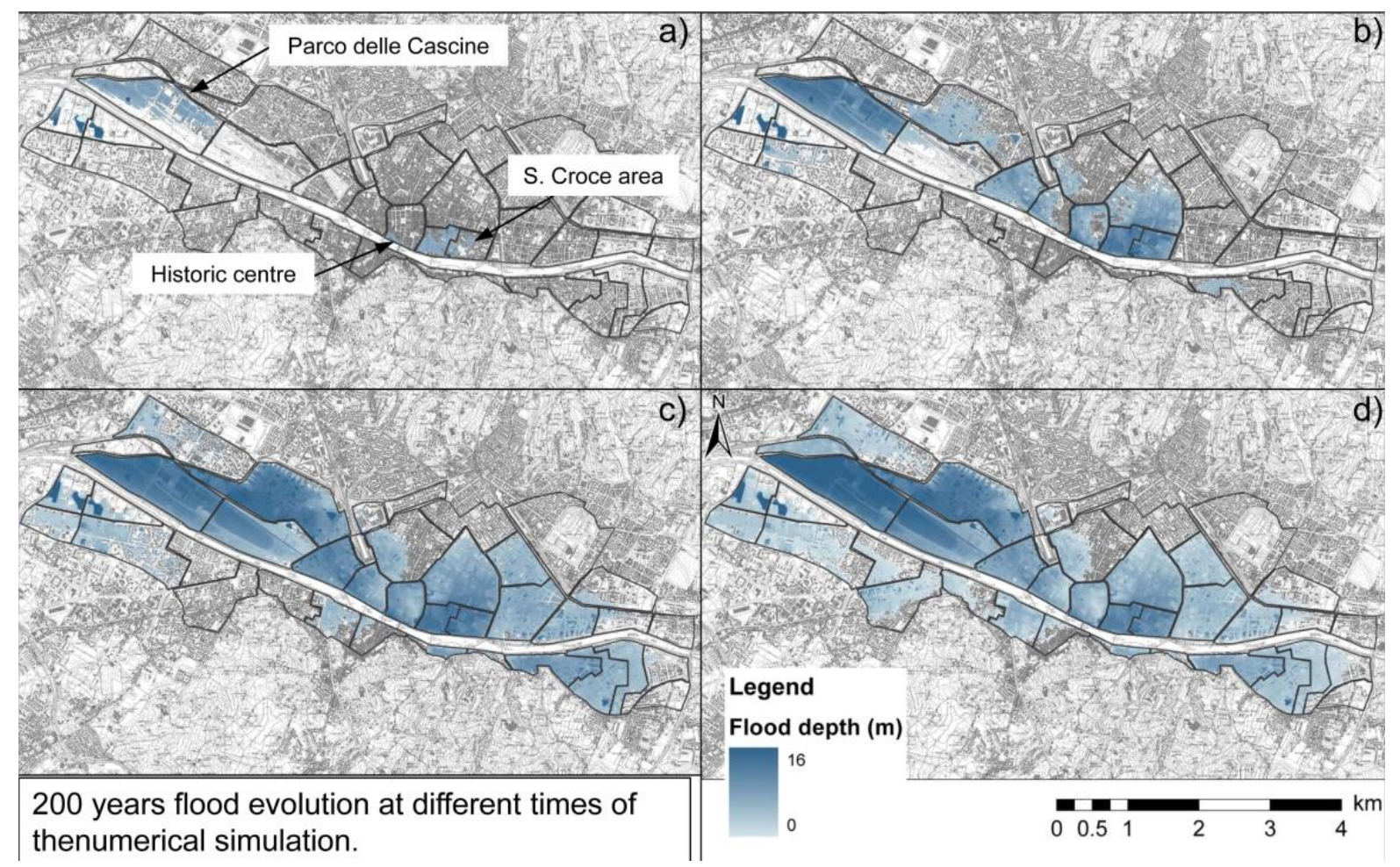

Fig. 6. Water depth in Florence after 16 (a), 18 (b), 22 (c), and $26 \mathrm{~h}$ (d) from simulation start of the $200 \mathrm{yr}$ flood event.

events allows us to argue that in the city of Florence the main driver in the flood depth and extent is the terrain morphology.

\subsection{Damage model application}

In order to better test the proposed flood damage method and focus on specific practical problems in its application, a small area is chosen, which is the most affected by floods in both scenarios. The St. Croce area was also one of the most damaged in the 1966 flood and it is famous for the loss of many artistic masterpieces in churches and museums and manuscripts in the National Library.

Franciscans arrived there in the 13th century and the church of St. Croce, which gives its name to the neighbourhood, was completed in 1433 during the Renaissance period when the area was almost completely urbanized. During its history the St. Croce area was characterized by leather craftsmanship whose memory remains in the streets' toponymy and in a large amount of leather-good shops still active. Now this area is a tourist attraction and hotels, restaurants and other facilities are widespread.

This study area covers about $0.5 \mathrm{~km}^{2}$ and contains $58 \mathrm{sec}-$ tions of the 2001 census, counting a total of 4081 inhabitants.

The representative main damage categories selected for the study area are structures, household contents and commercial contents.

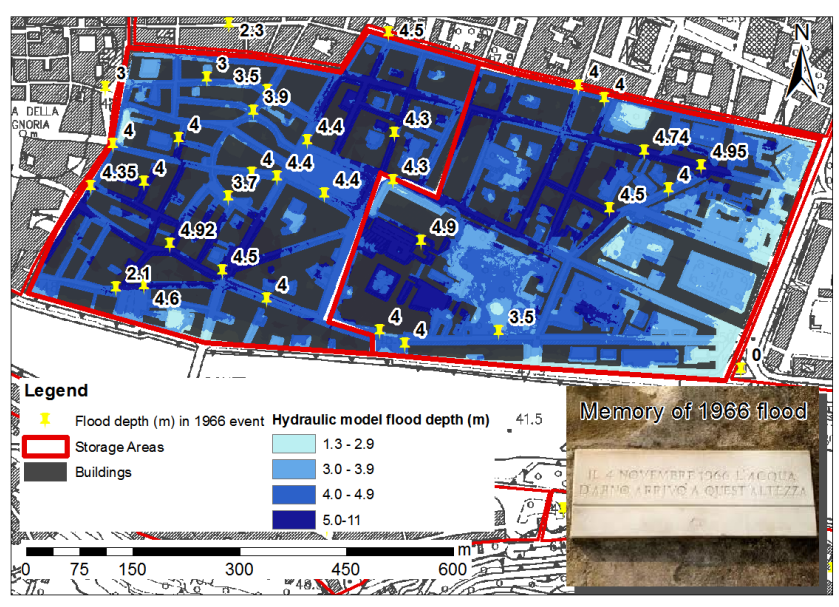

Fig. 7. Spatial detail for the St. Croce district of the flood depth estimated for the $200 \mathrm{yr}$ event (shades of blue) and maximum water depth from the 1966 event historical plates (figures). An example picture of such plates is given in the inset.

For structures and household contents, the following subcategories are present:

- four storey buildings with cellar (Renaissance's buildings); 


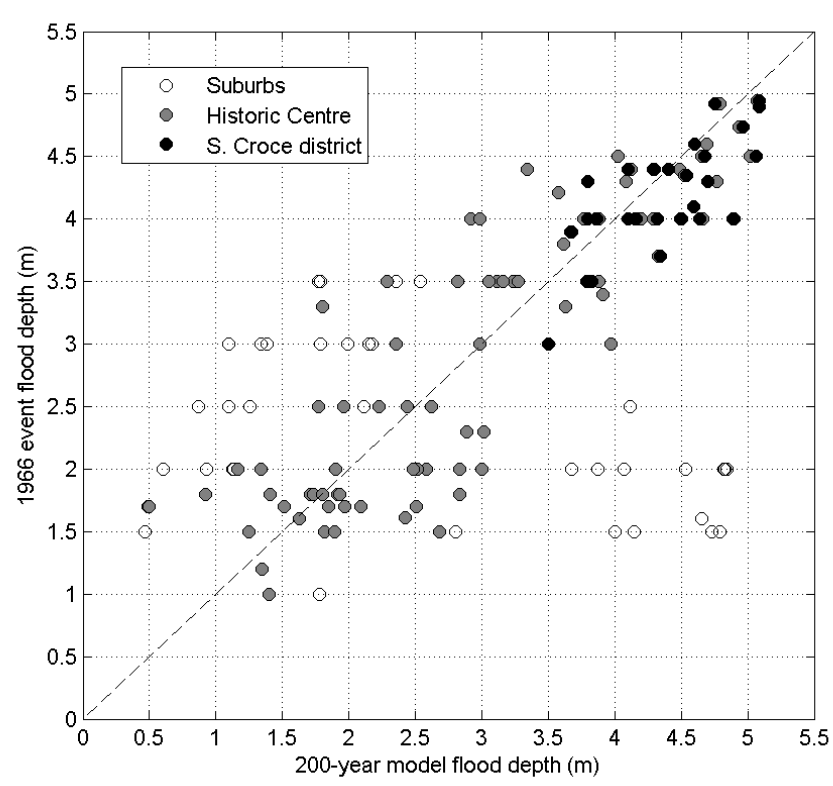

Fig. 8. Scatter plot of the hydraulic model flood depth estimated for the $200 \mathrm{yr}$ event vs maximum water depth from the 1966 event historical plates. Different symbols are used for different study areas as in Fig. 5.

- two storey buildings with cellar (post-unitary buildings).

For commercial contents, the following sub-categories are considered as representative of about $90 \%$ of commercial activities at risk:

- leather-good shops;

- tourist accommodations and services (hotels, restaurants, cafés).

For these main classes the vertical distribution of economic value is first defined. For the structures and the household contents it is assumed that each floor has the same value and that the cellar is the $6 \%$ of total value (Fig. 9). For commercial activities, which are usually located in the ground floor in a dual-use building, it is assumed that $100 \%$ of activity value is in the ground floor and cellar (used as warehouse or winery). Buildings with more than two storeys are all treated as four storey ones.

With the above assumption we can create stage-damage (\%) curves (Fig. 9) even if we do not have any real damage validation data for the study area. The stage-damage curves for the structures made for this case study are pretty similar to the Palermo case study ones (Oliveri and Santoro, 2000) because they share some assumptions and the building characteristics are comparable. It is assumed also that we have no direct damage for the above categories before water reaches a depth of $0.25 \mathrm{~m}$. This threshold depth represents the average elevation of the building entrance door upon the road level as a)

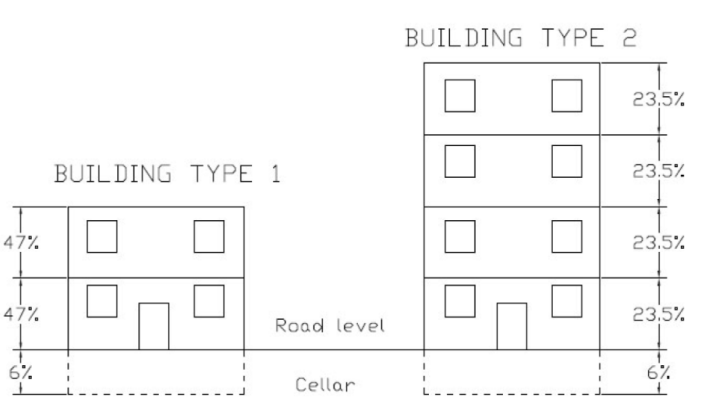

b)

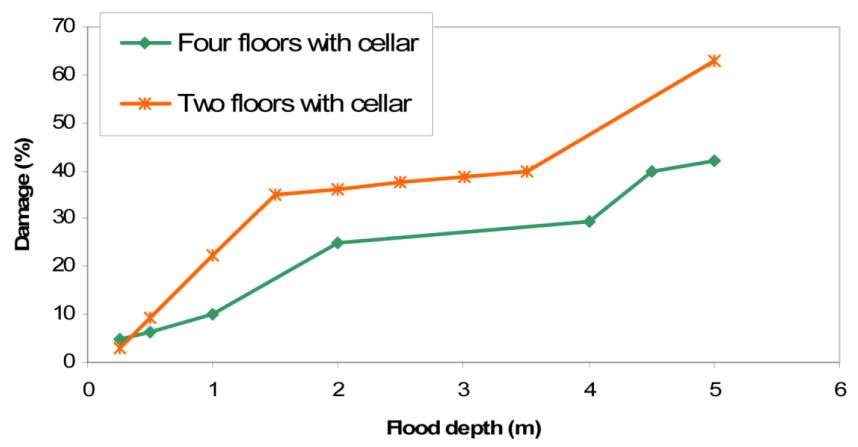

Fig. 9. Reference scheme for the vertical value distribution (a) and structural stage-damage relationships (b) for buildings.

in Oliveri and Santoro (2000). This is a simplifying assumption because most buildings are not waterproof and could be seriously damaged even with a lower flood depth, depending on the efficiency of the local sewage system. Waterproofing buildings, installing backflow valves or drainage lines, can be valid operations to reduce flood damages, but it is a personal cost for homeowners who are frequently uniformed about the risk to their properties (see Sect. 6).

The average flood depth for census section is computed using the raster calculator GIS tool, then the application of stage-damage curves leads to the average damage maps for each main class.

Economic value is estimated with Eqs. (8), (9) and (10) where $Q_{\text {imm }}$ is about $4000 € \mathrm{~m}^{-2}$ in the study area. $V_{\text {ad }}$ for leather-good shops is estimated as $76000 €$ employee $^{-1}$ (assuming that $L=10, T_{\mathrm{s}}=0.25 \mathrm{yr}$, $M=0$, see Sect. 3.4); for tourist accommodation and services $V_{\text {ad }}$ is $13000 €$ employee $^{-1}$ (assuming $L=10$, $T_{\mathrm{s}}=0.02 \mathrm{yr}, M=68500 €$ ) (see Table 2). All monetary values are estimated with fourth quarter data of 2011.

\section{Results}

The intermediate results of the procedure, i.e. the $200 \mathrm{yr}$ percent damage map, the economic value and the $200 \mathrm{yr}$ 


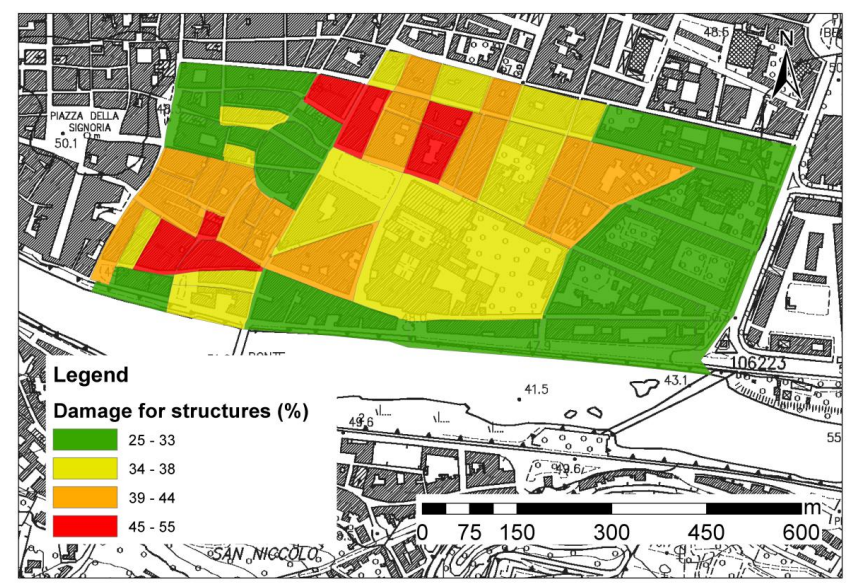

Fig. 10. Per cent structural damage for buildings in the St. Croce district for the $200 \mathrm{yr}$ flood.

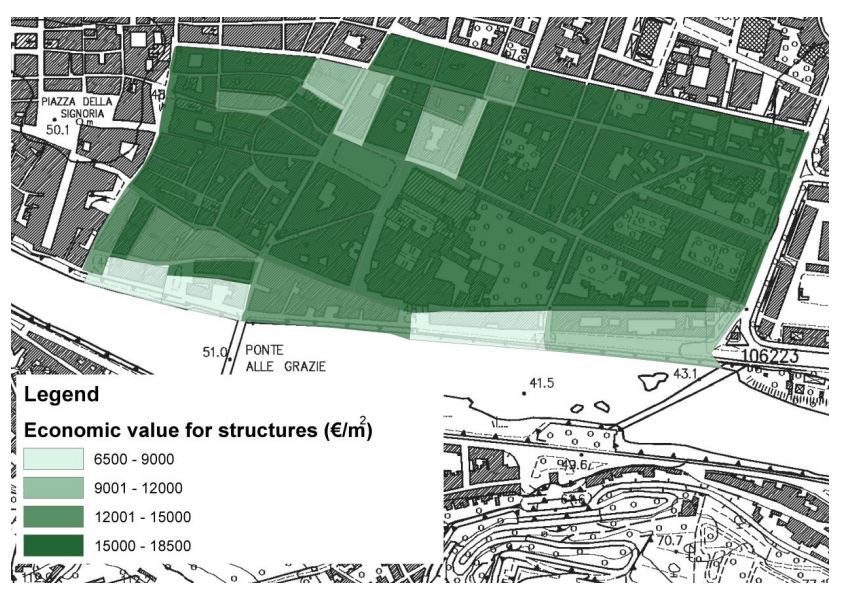

Fig. 11. Map of the monetary value for structures $\left(€ \mathrm{~m}^{-2}\right)$ referred to the census section unit surface.

monetary damages, are shown in Figs. 10 through 12 for the sample category of structures.

The average per cent damage to structures is $7 \%$ for a $100 \mathrm{yr}$ flood and $36 \%$ for a $200 \mathrm{yr}$ flood, $20 \%$ and $85 \%$ for commercial contents, $7 \%$ and $30 \%$ for household contents. As shown in Fig. 10, the spatial distribution of the per cent damage reflects both the pattern of the flood depths (see Fig. 7) and the location of specific high vulnerability buildings.

As shown in Fig. 11, the spatial distribution of the economic value of the structures, which is given as per unit area of census section, is quite heterogeneous, also reflecting the combination of different building density and building types. The resulting map of the $200 \mathrm{yr}$ flood structural damage, shown in Fig. 12, is even more variable than its two main components, covering a whole order of magnitude. This is a

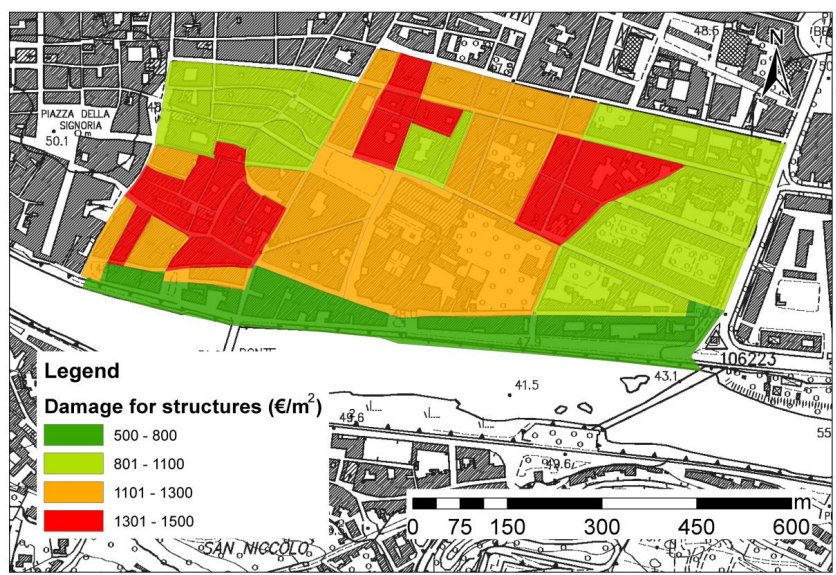

Fig. 12. Monetary damage to the structures $\left(€ \mathrm{~m}^{-2}\right)$ for the $200 \mathrm{yr}$ flood.

hint of a positive correlation between value and vulnerability, which is a further exacerbating risk factor.

The total average monetary damage in the study area, considering all the categories, is $340 € \mathrm{~m}^{-2}$ for the $100 \mathrm{yr}$ scenario and $1750 € \mathrm{~m}^{-2}$ for the $200 \mathrm{yr}$ scenario (see also Table 3 for the detail of the single categories).

Through total damage values we can build the damagefrequency relationship for the study area and compute the EAD (Eq. 11) that enables us to evaluate flood risk. EAD results in about $5.6 \mathrm{M} \mathrm{yr}^{-1}, 14 € \mathrm{~m}^{-2} \mathrm{yr}^{-1}$ for the St. Croce area referring to census unit surface area. This value does not include other direct damages such as cleaning costs, infrastructure damages or cultural asset loss and indirect damages. EAD could be corrected using building density to estimate the average flood risk for built surface. Here the building density is $57 \%$ so risk becomes about $24.5 € \mathrm{~m}^{-2}$ of building footprint.

Figure 14 shows the spatial distribution of EAD for census section units in the St. Croce district. The map highlights many census sections where flood risk is larger than the average value (violet and magenta sections). The spatial distribution of higher flood risk sections reflects both the pattern of the flood depths (Fig. 7) and the exposure of various assets. In fact the largest damage at a constant flood level is located where commercial density is higher (e.g. the most of the buildings are dual-use buildings) or generally where the monetary value for the structures (and consequently for household contents) is higher (Fig. 11).

\section{Flood protection measures}

Starting from the details of a micro-scale quantitative analysis, we can try a more objective evaluation of the economic cost-effectiveness of risk reduction measures. We will take the retrofitting one as a first example. This possible measure for risk reduction in the area is still being debated. 
Table 3. Total damages and average damages for census unit surface in the study area.

\begin{tabular}{lrrrr}
\hline $\begin{array}{l}\text { Damage } \\
\text { categories }\end{array}$ & $\begin{array}{r}100 \mathrm{yr} \text { flood } \\
(M €)\end{array}$ & $\begin{array}{r}100 \mathrm{yr} \text { flood } \\
\left(€ \mathrm{~m}^{-2}\right)\end{array}$ & $\begin{array}{r}200 \mathrm{yr} \text { flood } \\
(M €)\end{array}$ & $\begin{array}{r}200 \mathrm{yr} \text { flood } \\
\left(€ \mathrm{~m}^{-2}\right)\end{array}$ \\
\hline Structures & 84.5 & 211 & 449.6 & 1124 \\
Household contents & 41.5 & 103 & 197.3 & 493 \\
Commercial contents & 10.7 & 27 & 45.1 & 113 \\
\hline Total & 136.7 & 340 & 692 & 1750 \\
\hline
\end{tabular}

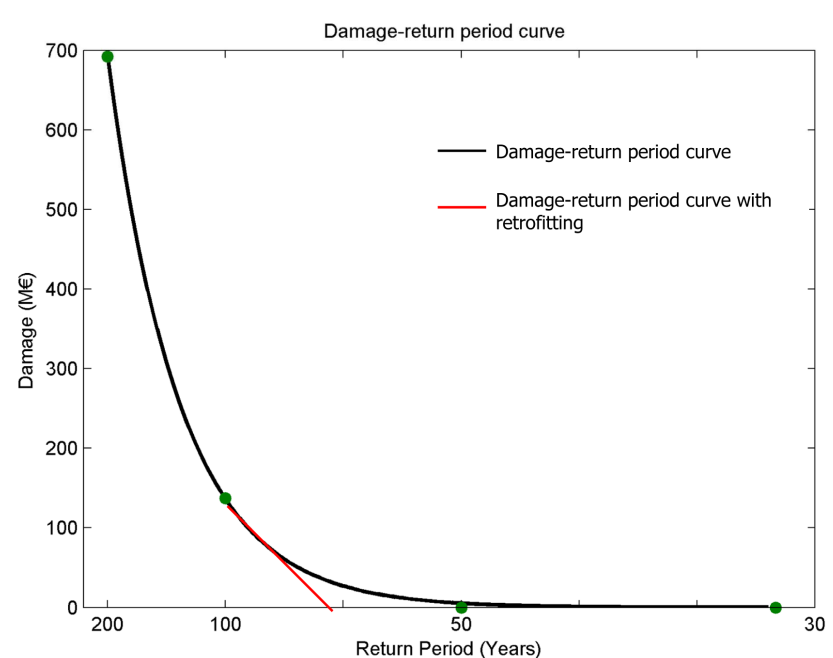

Fig. 13. Damage-return period curves for the St. Croce district, with and without building retrofitting.

Risk management strategies can be roughly divided into public and private ones: the first ones usually have a much stronger social valence and may often neglect strict costbenefit analysis. This is particularly true when elements at risk are human life or cultural heritage whose value cannot be monetized. Private interventions are instead strictly costbenefit driven. Tipically homeowners are directly interested in cost effectiveness of their investment in individual flood protection measures as a monetary reduction of future losses and/or insurance premiums.

Protecting Florence from floods is a national matter since 1966. According to hydraulic and flood hazard studies started since the late $60 \mathrm{~s}$, a system of storage areas in the upstream Valdarno region is considered the best way to avoid damages from $100 \mathrm{yr}$ return period floods, and $200 M €$ is the cost that was estimated in a 1998 general basin plan (Arno River Basin Authority, 2002b). But also individual precautionary measures on buildings, known as retrofitting methods (FEMA, 2009), can be effective in combination with basin-scale intervention. However, data about the effects of such measures are rare and consequently the efficiency of different precautionary measures is still unclear (Kreibich et al., 2005b). Signing a flood insurance can be another way to secure household

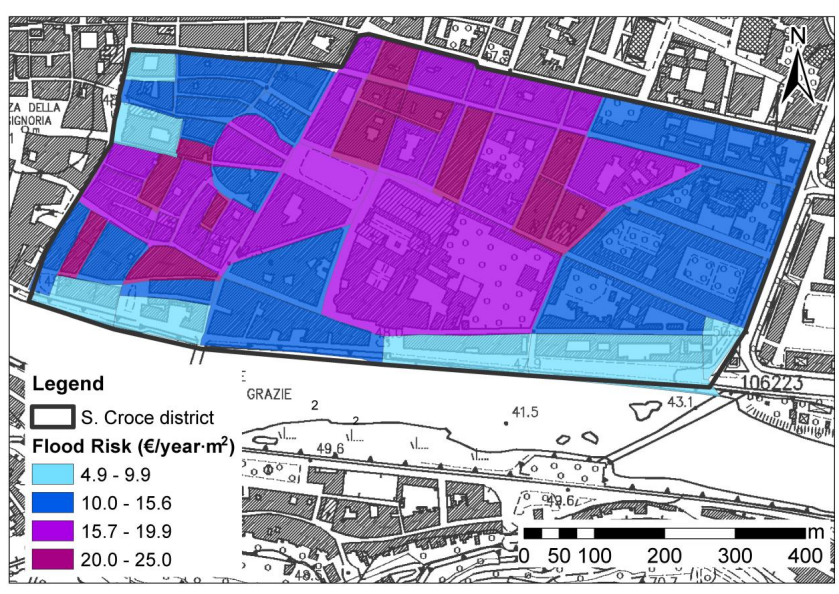

Fig. 14. Flood risk map for the St. Croce district $\left(€ \mathrm{~m}^{-2} \mathrm{yr}^{-1}\right)$. Values are for unit surface area of census sections.

contents and buildings. Flood insurance annual premiums in Italy currently start from $2 € \mathrm{~m}^{-2}$.

In the St. Croce area another considerable problem is the cultural assets at risk, including several movable masterpieces that are exhibited in the St. Croce museum and are hardly able to be relocated because of the site-specific nature of this museum.

Let us consider some retrofitting measures suitable for structures and household contents in the study area: flood adapted use and installation of backwater valves. The installation of the backwater valves is a crucial measure for the study area. Since the sewage network in Florence is very old and combined (i.e. same pipe systems for collecting storm runoff and wastewater) and not well maintained, a small but persistent flood depth (e.g. of the order of $0.10 \mathrm{~m}$ ) can cause the flooding of the cellars that lie $3 \mathrm{~m}$ under the road level. This occurs also in case of intense rainfall.

The costs here adopted for these measures are to be considered as local and come from the assessment of some experts from the sectors of construction and renovation.

For commercial activities flood adapted use means essentially not to use the cellar as a warehouse or winery in order to prevent damages to leather goods and other products.

Flood adapted use also means that only waterproofed building materials and furniture should be used and heating 
Table 4. Costs of retrofitting precautionary measures.

\begin{tabular}{lrr}
\hline Precautionary Measure & Cost & Annual instalment \\
\hline Backflow valve & $12.5 € \mathrm{~m} \mathrm{~m}^{-2}$ & $0.7 € \mathrm{~m}^{-2} \mathrm{yr}^{-1}$ \\
Raising electrical plant & $40-80 € \mathrm{~m}^{-2}$ & $5 € \mathrm{~m}^{-2} \mathrm{yr}^{-1}$ \\
Flood adapted use & $1000 € \mathrm{~m}^{-2}$ & $50 € \mathrm{~m}^{-2} \mathrm{yr}^{-1}$ \\
\hline
\end{tabular}

and other utilities like energy and gas should be moved upstairs. These precautions are very expensive but can be designed while renovating a flat and they imply additional restructuring costs, approximately $25 \%$ of the flat's value (1000 $€ \mathrm{~m}^{-2}$ in St. Croce area). Only the raising of electrical devices can cost approximately $40-80 € \mathrm{~m}^{-2}$.

Backwater valves stop the water from entering the building via the sewage network and can protect cellars for low water depth; installing a valve costs about 1000 €and means (for a medium flat of $80 \mathrm{~m}^{2}$ ) a cost of $12.5 € \mathrm{~m}^{-2}$. All of the above unitary costs refer to built surface area.

If we suppose that these costs can be paid in annual instalments for $30 \mathrm{yr}$ with a $3 \%$ rate we can compare the estimated average current flood risk for built surface areas (24.5€ $\mathrm{m}^{-2} \mathrm{yr}^{-1}$ ) with annual investment (Table 4) and with residual risk to discuss the benefits of flood risk mitigation measures.

We should remind that all the mentioned precautionary measures are considered as effective for water depths less than $1 \mathrm{~m}$ (Arno River Basin Authority, 2011; FEMA, 2009).

If we assume, for instance, that flood damage is zero before water reaches $1 \mathrm{~m}$ (e.g. with retrofitting methods applied) we could conclude that a $70 \mathrm{yr}$ event does not affect our study area.

As shown in Fig. 13 (red line), the adoption of retrofitting measures changes the shape of the damage-frequency curve with a consequent reduction of the area under the curve, quantifiable with Eq. (11).

With retrofitting measures a reduction of flood risk of about $5.3 € \mathrm{~m}^{-2}$ is expected with an average residual risk of $19.2 € \mathrm{~m}^{-2}$. This means that only backflow valve installation could be cost-effective. The cost of the raising of electrical installations is almost equal to risk reduction and represents the maximum reasonable investment suitable for those higher-risk sections (violet and magenta ones in Fig. 14). Flood adapted use instead is too expensive in comparison with estimated risk reduction.

In conclusion, the St. Croce area must be secured also with basin-scale interventions such as storage areas in the Valdarno region. The combination of basin-scale and individual measures with a large educational program and alert system can reduce significantly flood risk in Florence but with significant costs. Both, in cases of public or private interventions, micro-scale flood risk assessment, based on census unit, enables us to understand quantitatively and with a good accuracy the local effectiveness of different management strategies.

\section{Conclusions}

After the 60/2007/EC Directive, flood risk management plans are mandatory and monetary evaluation and costbenefit analysis become the primary ways to choose the best flood risk mitigation protection strategy. This is particularly true when private homeowners are directly involved in the choice of the mitigation measures, such as retrofitting methods suitable for their property.

Flood hazard maps have to be systematically implemented, hence requiring both accuracy in results and easiness in model set-up. From this point of view it is widely suggested that coupled 1-D/2-D models can be considered as the best compromise. The parsimonious quasi-2-D hydraulic model described in this paper has many advantages in terms of easy set-up through commonly used free software such as the HEC family. It is also here evaluated as reproducing well the flood extent and the flood depths of events of similar magnitude with a high-resolution and up-to-date DSM. The capability of the parsimonious hydraulic model to describe the flood depth pattern in similar scenarios, estimated by comparison with marble-plate records of a historic flood in the city of Florence, reaches in the downtown area a bias of a very few centimetres compared to an average flood depth of about $2 \mathrm{~m}$ and a determination coefficient of 0.73 .

The main disadvantage of this quasi-2-D approach is the subjectivity in the storage cells definition and the fact that the storage cells start to fill in the lowest part, so that the detailed flood dynamic is neglected. More efforts should be addressed in this direction in order to find a suitable model to represent an urban area with this considerable building density and dimension. Damage models are likely the link, in the risk estimation chain, that require more advancement and further deepening. Critical, only partially resolved problems are the parameter estimation and the definition of stage-damage curves with local representativeness. Greater efforts have to be focused in vulnerability and exposure studies in order to bring that part of a risk assessment study to the same level of precision as from hydraulic simulations. In fact the damage assessment is much more uncertain than the hazard assessment, thus the selection of the flood loss model is crucial in the final risk estimation. The flood damage is influenced by numerous parameters such as flood velocity, flood duration, and precautions, so the use of flood depth as unique parameter for the damage estimation is clearly an approximation (Merz et al., 2004; Apel, 2008; Kreibich et al., 2005a). In this respect further studies are necessary to evaluate the performance of the proposed methodology and to corroborate its general applicability.

This preliminary case study highlights that census section scale could be an optimal micro-scale discretization and data reference for flood risk assessment in urban areas. It allows one to estimate high-detail potential losses and flood risk for representative categories of the urban asset such as buildings, household contents and commercial activities and to 
represents results with high-resolution risk maps. Even if single properties or businesses cannot be resolved at this scale, it may be said that most of the variability of the economic value at risk can be resolved, in dense urban areas, at the scale of building blocks. These quite often coincide with census sections. Furthermore, the results of flood risk assessment at the census section scale can be easily aggregated to whatever upper scale is needed given that they are geographically defined as contiguous polygons. Census section data cover a whole national territory, they are a georeferenced mesh more refined where population density increases, and they are often updated and available in many countries in the EC and worldwide.

In the study area, potential losses, estimated with the proposed method, for a $100 \mathrm{yr}$ return period flood are about $136 M €$ and $691 M €$ for a $200 \mathrm{yr}$ flood including only direct damages to buildings, household contents and commercial activities in the St. Croce area. This is the most affected neighbourhood in downtown Florence. The estimated aver-

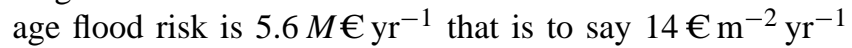
referring to census section surface area and $24.5 € \mathrm{~m}^{-2} \mathrm{yr}^{-1}$ referring to building footprint. Considering the official per capita income for the city of Florence in 2010, that is $16610 € \mathrm{yr}^{-1}$, and for the census' 4081 inhabitants, it turns out that the flood risk in the St. Croce area amounts to about $8.3 \%$ of official per capita income.

These values have been used to compare different retrofitting measures; concluding that installing backflow valves and raising electrical devices could be cost effective but a substantial flood risk mitigation could be obtained only with the combination of public and private interventions.

The hydraulic model enhancement may be attained through an automatic standard for drawing storage cells, while a better parameterized (vulnerability and exposure) estimation for the damage model could return more reliable results; the census section method can be further widened adding more damage categories and even non-monetizable classes such as cultural assets.

Acknowledgements. The authors thank the municipality of the city of Florence, in the person of Giovanni Menduni, for providing the digital surface model and for useful discussions on the interpretation of hydraulic model results and socio-economic data.

Edited by: P. Tarolli

Reviewed by: three anonymous referees

\section{References}

Agenzia delle Entrate: Sintesi degli studi di settore, 2009.

Agenzia del territorio: Istruzione per la determinazione della consistenza degli immobili urbani per la rilevazione dei dati dell'Osservatorio dl Mercato Immobiliare, 2001.

Agenzia del territorio: rapporto Immobiliare 2011 - Immobili a destinazione terziaria, commerciale, produttiva, 2011.
Apel, H., Thieken, A. H., Merz, B., and Blöschl, G.: Flood risk assessment and associated uncertainty, Nat. Hazards Earth Syst. Sci., 4, 295-308, doi:10.5194/nhess-4-295-2004, 2004.

Apel, H., Aronica, G. T., Kreibich, H., and Thieken, A. H.: Flood risk analyses- how detailed do we need to be?, Nat. Hazards, 49, 79-98, 2008.

Arno River Basin Authority: Perimetrazione delle aree a rischio sull'asta principale del fiume Arno e sugli affluenti nel tratto di rigurgito, 1999.

Arno River Basin Authority: Analisi dei battenti idrici sull'asta principale del fiume Arno e su alcuni dei principali affluenti (Sieve, Elsa, Era), 2002a.

Arno River Basin Authority: Progetto di piano stralcio per l'assetto idrogeologico, 2002b.

Arno River Basin Authority: Convenzione 13 ottobre 2010 rep. n. 1030 tra dipartimento della Protezione Civile e Autorità di bacino del fiume Arno. Area tematica 1: sviluppo di sistemi di sicurezza locale, 2011.

Barredo, J. I.: Normalised flood losses in Europe: 1970-2006, Nat. Hazards Earth Syst. Sci., 9, 97-104, doi:10.5194/nhess-9-972009, 2009.

Bates, P. D. and De Roo, A. P. J.: A simple raster-based model for flood inundation simulation, J. Hydrol., 236, 54-77, 2000.

Begnudelli, L., Sanders, B., and Bradford, S.: Adaptive GodunovBased Model for Flood Simulation, J. Hydraulic Eng., 134, 714 725, 2008.

Büchele, B., Kreibich, H., Kron, A., Thieken, A., Ihringer, J., Oberle, P., Merz, B., and Nestmann, F.: Flood-risk mapping: contributions towards an enhanced assessment of extreme events and associated risks, Nat. Hazards Earth Syst. Sci., 6, 485-503, doi:10.5194/nhess-6-485-2006, 2006.

Chen, A. S., Evans, B., Djordjević, S., and Savić, D.: A coarse-grid approach to representing building blockage effects in 2-D urban flood modeling, J. Hydrol., 426-427, 1-16, 2012.

Dutta, D. and Herath, S.: Methodology for flood damage assessment using GIS and distributed Hydrologic model, INCEDE, IIS, University of Tokyo, 1998.

Elmer, F., Hoymann, J., Düthmann, D., Vorogushyn, S., and Kreibich, H.: Drivers of flood risk change in residential areas, Nat. Hazards Earth Syst. Sci., 12, 1641-1657, doi:10.5194/nhess-12-1641-2012, 2012.

Ernst, J., Dewals, B. J., Detrembleur, S., Archambeau, P., Erpicum, S., and Pirotton, M.: Micro-scale flood risk analysis based on detailed 2-D hydraulic modelling and high resolution geographic data, Nat. Hazards, 55, 181-209, 2010.

FEMA: Homeowners guide to retrofitting, six ways to protect your home from flooding, P-312, 2nd Edn., 2009.

Genovese, E.: A methodological approach to land use based flood damage assessment in urban areas: Prague case study, European Commission, Joint Research Centre, 2006.

Horritt, M. S. and Bates, P. D.: Predicting floodplain inundation: raster-based modelling versus the finite-element approach, Hydrol. Process., 15, 825-842, 2001.

Huang, S., Rauberg, J., Apel, H., Disse, M., and Lindenschmidt, K.-E.: The effectiveness of polder systems on peak discharge capping of floods along the middle reaches of the Elbe River in Germany, Hydrol. Earth Syst. Sci., 11, 1391-1401, doi:10.5194/hess-11-1391-2007, 2007. 
Hunter, N. M., Bates, P. D., Neelz, S., Pender, G., Villanueva, I., Wright, N., Liang, D., Falconer, R., Lin, B., Waller, S., Crossley, A., and Mason, D.: Benchmarking 2-D hydraulic models for urban flooding, Water Management, 161, 13-30, 2008.

ICPR (International Commission for the Protection of the Rhine): Rhine-Atlas, ICPR, Koblenz, available at: http://www.rheinatlas. de (last access: 26 April 2013), 2001.

Jonkman, S., Bočkarjova, M., Kok, M., and Bernardini, P.: Integrated hydrodynamic and economic modelling of flood damage in the Netherlands, Ecol. Economics, 66, 77-90, 2008.

Kang, J., Su, M. D., and Chang, L. F.: Loss functions and framework for regional flood damage estimation in residential areas, J. Mar. Sci. Technol., 13, 193-199, 2005.

Kok, M.: Damage functions for the Meuse river floodplain, Communication paper to the Joint Research Centre, Ispra, Italy, 2001.

Kreibich, H., Thieken, A., Muller, M., and Merz, B.: Precautionary measures reduce flood losses of household and companiesinsights from the 2002 flood in Saxony, Germany, Water Resour. Res., 41, 851-859, 2005a.

Kreibich, H., Thieken, A. H., Petrow, Th., Müller, M., and Merz, B.: Flood loss reduction of private households due to building precautionary measures - lessons learned from the Elbe flood in August 2002, Nat. Hazards Earth Syst. Sci., 5, 117-126, doi:10.5194/nhess-5-117-2005, 2005b.

Kreibich, H., Piroth, K., Seifert, I., Maiwald, H., Kunert, U., Schwarz, J., Merz, B., and Thieken, A. H.: Is flow velocity a significant parameter in flood damage modelling?, Nat. Hazards Earth Syst. Sci., 9, 1679-1692, doi:10.5194/nhess-9-1679-2009, 2009.

Lehner, B., Döll, P., Alcamo, J., Henrichs, T., and Kaspar, F.: Estimating the impact of global change on flood and drought risk in Europe: a continental integrated analysis, Climate Change, 75, 273-299, 2006.

Lindenschmidt, K.-E., Herrmann, U., Pech, I., Suhr, U., Apel, H., and Thieken, A.: Risk assessment and mapping of extreme floods in non-dyked communities along the Elbe and Mulde Rivers, Adv. Geosci., 9, 15-23, doi:10.5194/adgeo-9-15-2006, 2006.

Lugeri, N., Genovese, E., Lavalle, C., and De Roo, P. D.: Flood risk in Europe: analysis of exposure in 13 countries. Institute for environment and sustainability, Joint Research Centre, 2006.

Luino, F., Bidoccu, M., Cirio, C. G., Agangi, A., Giulietto, W., Godone, F., and Nigrelli, G.: Application of a model to the evaluation of flood damage, Geoinformatica, 13, 339-353, 2009.

Malguzzi, P., Grossi, G., Buzzi, A., Ranzi, R., and Buizza, R.: The 1966 "century" flood in Italy: a meteorological and hydrological revisitation. J. Geophys. Res., 111, D24106, doi:10.1029/2006JD007111, 2006.
Merz, B., Kreibich, H., Thieken, A., and Schmidtke, R.: Estimation uncertainty of direct monetary flood damage to buildings, Nat. Hazards Earth Syst. Sci., 4, 153-163, doi:10.5194/nhess-4-1532004, 2004.

Messner, F. and Meyer, V.: Flood damage, vulnerability and risk perception-challenges for flood damage research. Flood Risk Management - Hazards, Vulnerability and Mitigation Measures, Nato Science Series, Springer Publisher, 2005a.

Messner, F. and Meyer, V.: National Flood damage Evaluation Methods, A review of applied methods in England, The Netherlands, The Czech Republic and Germany. UFZ-discussion papers, 2005b.

Messner, F., Penning-Rowsell, E., Green, C., Meyer, V., Tunstall, S., and van der Veen, A.: Evaluating Flood damages: guidance and recommendations on principles and methods, FLOODsite Report Number T09-06-01, 2007.

Mignot, E., Paquier, A., and Haider, S.: Modelling floods in a dense urban area using 2-D shallow water equations, J. Hydrol., 327, 186-199, 2006.

Ministry of Environmental: Classificazione dei comuni italiani in base al livello di attenzione per il rischio idrogeologico, 2000.

Munich RE: Significant natural catastrophes 1980-2011, Geo Risk Research, 2012.

Oliveri, E. and Santoro, M.: Estimation of urban structural flood damages: the case study of Palermo, Urban Water, 2, 223-234, 2000.

Penning-Rowsell, E., Johnson, C., Tunstall, S., Tapsell, S., Morris, J., Chatterton, J., and Green, C.: The benefits of flood and coastal defence: techniques and data for 2003, Flood Hazard Research Centre, Middlesex University, UK, 2003.

Reese, S., Markau, H.-J., and Sterr, H.: MERK Mikroskalige Evaluation der Risiken in überflutungsgefährdeten Küstenniederungen, Abschlussbericht, Kiel, 2003.

Schubert, J. E. and Sanders, B. F.: Building treatments for urban flood inundation models and implications for predictive skill and modeling efficiency, Adv. Water Resour., 41, 49-64, 2012.

Su, M. D., Kang, J. L., Chang, L. F., and Chen, A. S.: A grid based approach to regional flood damage assessment, J. Mar. Sci. Technol., 13, 184-192, 2005.

van Alphen, J., Martini, F., Loat, R., Slomp, R., and Passchier, R.: Flood risk mapping in Europe, experiences and best practices, J. Flood Risk Manage., 2, 285-292, 2009.

van der Veen, A. and Logtmeijer, C.: Economic hotpots: visualizing vulnerability to flooding, Nat. Hazards, 36, 65-80, 2004. 